ISSN 2308-1902 Актуальні проблеми української літератури і фольклору. 2017. № 25.

УДК 821.161.2 Стус

Ольга ПУНІНА

к. філол. наук, доцент, Донецький національний університет імені Василя Стуса

\title{
ІНТЕРПРЕТАЦІЯ ОСОБИСТОСТІ ВАСИЛЯ СТУСА В ХУДОЖНІЙ СТРІЧЦІ РОМАНА ВЕРЕТЕЛЬНИКА «ПАЛІМПСЕСТ»
}

У статті ключовим об’єктом дослідження постає творча особистість Василя Стуса, якою вона презентована в короткометражному художньому фільмі 2014 року Романа Веретельника «Палімпсест». Доведено, що режисер працює в межах експресіоністичної поетики й інтерпретує постать Стуса як креатора, за допомогою знакового для нього образу душі.

Ключові слова: образ, експресіонізм, художній фільм, особистість, інтерпретація, смисл, літературно-побутові матеріали.

Перша спроба художнього осмислення біографічної і творчої особистості Василя Стуса засобами кіномистецтва - фільм Романа Веретельника «Палімпсест» 2014 року [3], знятий за мотивами однойменної моновистави Миколи Мерзлікіна (Національний центр театрального мистецтва ім. Леся Курбаса, 2004 рік). Його короткометражна художня стрічка з’являється за два десятиліття опісля документальної кінотрилогії Станіслава Чернілевського «Просвітлої дороги свічка чорна. Пам’яті Василя Стуса» (1992), в якій ігрові елементи $\epsilon$ лише прийомом. I необхідність наукового прочитання цієї інтерпретаційної моделі письменницької індивідуальності Стуса зумовлюється потребою представити якомога повнішу картину твореного і до сьогодні мистецькими формами образу, за словами Дмитра Стуса, «людини 3 біографією» $[9$, с. 8$]$, його смислопороджень. Тим паче, що ані кінокритика, ані літературознавча думка донині не спромоглися опрацювати Веретельників «Палімпсест».

Режисер пропонує бачення особистості Василя Стуса з позиції гри одного актора - Галини Стефанової, якій вдається витворити цілісний образ поета i людини шляхом зміни монологічних точок зору, а саме - персонажів-голосів (матері, судді, самого Стуса). Формально це стає можливим завдяки застосованому принципу палімпсестності (накладання і взаємодії) епізодів. В 
основу більшості епізодів закладено знакові щодо постаті Стуса меседжі 3 літературно-побутових матеріалів - спогадів, листів, а також художніх творів поета. Пошук взаємозв'язку між ними приводить до спільного знаменника наскрізного образу душі, що чітко корелює з особистістю Стуса-креатора.

Так, розпочинається художня стрічка молитвою до Богородиці, яку промовляє жінка з сумним і зосередженим поглядом - мати (і узагальнений образ матері, і конкретно - Їлина Стус): «Під Твою милість прибігаєм, Богородице Діво. Молитвами нашими у журбах незгорд, а від бід визволи нас, єдина чиста благословенна. Прийми молитви намі, донеси їх Синові своєму, Богові нашому, щзоб спас тебе ради душі намі», й монологом про намого Васю. Режисер i сценарист Роман Веретельник кінообраз матері вибудовує за інтерв’ю-спогадами 1990 року Їлини Стус, роблячи акцент на словах про знищення сина: «Ви ж його з'їли? З'їли. То що ж ви хочете?» [2, с. 142]. Паралельно епізод супроводжується звуковим фоном - жваві людські розмови, сміх під дзвін посуду, що нагадує веселе застілля. Сприймається такий супровід читання молитви й омовлення материнського смутку як насмішка: світові нема діла до трагедії матері. Душі наші в цьому контексті материних слів набувають семантики всепрощення.

Наступний епізод розвиває тему знищення і поета, до чого відсилають кадри зимових дерев, що тягнуться вздовж залізничної колії (поетична збірка Стуса «Зимові дерева» 1970 року видання), і людини, яку увиразнює музичний супровід - пісня «Співають, плачуть солов'ї...» на слова Олександра Олеся, поезія «Чари ночі», яку співав Василь Стус, про що пише в листі до дружини і сина від 15 січня 1984 року [8, с. 456]. В цьому чорно-білому, що підкреслює драматичність, епізоді режисер подає образ судді, зображаючи його в гротескному форматі. Поголена акторка вдається до надмірної експресії у процесі одночасного читання-проспівування драматичним сопрано «Вироку у справі Василя Стуса» від 7 вересня 1972 року, при цьому на передньому плані брудне скло, із розводами, за яким ніби відбувається виголошення вироку. 
Переходами від епізоду до епізоду режисер обирає світло прожектора, що засліплює. Такий хід прочитується з підтекстом - Стус перебуває серед сліпих на правду, той же суддя, людей.

Принцип палімпсестності на цьому етапі художньої стрічки вступає в дію: накладається почергово зображення персонажа судді й Стуса-арештанта, судді й матері 3 документальним врізками - Стусова хата в Донецьку на вулиці Чувашській 19, де минуло дитинство і юність. В одній точці сходяться кілька поглядів на письменника: гротескно суддівський - звинувачувальний (зберігав, порочив, зводив), власне авторський, що характеризує поняття самозаглиблення, і материнський - його маркує глибоке почуття любові за дитиною, якій не дали жити. Власне авторський погляд базується на листі Василя Стуса до дружини від листопада-грудня 1984 року, в якому вдруге арештований Стус аналізує свій внутрішній стан і творчі процеси: «Був мені сон - і я збагнув - у сні-чому я, слава Богу, не такий, як усі. [...] Це вже другий чи третій віщий сон, у якому я прозріваю те, чого не міг збагнути при світлі розуму. О, які прекрасні прозові сюжети мені сняться! Які добрі вірші (як літні дощі!) мені спадають на голову - на самоті, без запису, без конкрецій, а так, як віщий дар (überlieferung, кажуть німиі), як сяєво жар-птищі» [8, с. 479]. Ключовими в цьому фрагменті листа стають міркування про інакшість (не такий, як усі) і відчуття віщого дару. Акторці Галині Стефановій вдається передати саме таке самоусвідомлення поета завдяки обраним голосовим модуляціям - розмірене, спокійне читання від імені Стуса-персонажа, що контрастує з нервовим ігровим (чекав-ква-ква-ква) читанням вироку суддею.

У контексті знущального вироку натяк на аспірантське життя гротескним суддею у «Палімпсесті» відсилає до київського періоду Василя Стуса - у фільми це увиразнено документальними кадрами тогочасного Києва, зокрема фігурують арка Дружби Народів, центральний універмаг, музичним супроводом - «Київський вальс» Платона Майбороди. Зв'язуючи ці кадри 3 наступним, акторка у світлі прожектора знімає одяг, тримає руки вверх і 
обертається довкола себе, ніби під час огляду кимось, - прочитується часопросторове розмежування: життя-тут, в ув'язненні, і життя-до, київське чи то пак із родиною, з яким єднає спогад. I саме нинішнє, життя-тут арештанта, в інтерпретації режисера продукує та гартує Стуса не такого, як усі.

Ув'язнення, попри його суто фізичне неприйняття, дає можливість особистості Василя Стуса творити: «Дасть Біг - усе изе оплатиться віршами. Пошли, Боже, натхнення на мою стрижену голову!» [8, с. 67]. Слід у контексті цього актуалізувати знання про першорядне місце людини як творця саме в естетиці експресіонізму [10, с. 632-633]. Галина Стефанова художньо перевтілюється в такого креатора, читаючи колаж із його епістолярію, художніх творів й одного 3 поцінованих ним поетів - Леоніда Кисельова. У пропонованому сценаристами колажі знакова роль відведена відчуттю самотності: із листів до рідних - «[...] роздумувати не так легко - на спорожнілій території пам'яті» [8, с. 229], «Потреб якихось не маю. Можна сказати - все в мене є, хоч і не маю нічого» [7, с. 485], «Переваги мої тутешні: самота, спокій, самозосередження» [8, с. 67]; із поетичної збірки «Час творчості» - «Бальзаку, заздри: ось вона, сутана, / $i$ тиша, $i$ самотність, $i$ nimbмa» [6, с. 17]. Підкреслює цей образ самотнього креатора режисерський хід: чорно-біла гама і зображене крупним планом умиротворене обличчя, ще одна деталь - рука, яка тримається за грати. Документальна вставка у подальшому перебігу стрічки Веретельника - коментар Євгена Сверстюка до ймення Базилеос, як він звертався до Стуса в умовах ув’язнення, - доповнює образ самотнього креатора (до речі, в есеї «Базилеос» Сверстюк зауважує, що за сутністю своєю «він був дуже самотній» [1, с. 427]) додатковим смисловим навантаженням - це людина, яка ігнорувала тиск обставин, якій подобається виклик німій тищі.

Отакий Василь Стус-арештант, витворений грою акторки Стефанової, увиразнюється і читанням нею фрагмента поезії зі збірки «Палімпсести» «Ці виски, изі скрики під вітром злітають угору. / Все вгору $і$ вгору - над небо, над 
ISSN 2308-1902 Актуальні проблеми української літератури і фольклору. 2017. № 25.

вечір, над ніч. / Лікуй висотою цฺю душу, ласкаву і хору, / в смертельнім ширянні тримайся і ранку не клич. / Землі - залегкі ми. I нас простовисно підносить / цей тлум навіженства, цей клекіт правічних волінь» [7, с. 184], де акцент падає на образ ласкавої $i$ хорої душі, що потребує гоєння висотою, тобто Божественним началом. Цей поетичний образ перегукується з біографічним Стусом, який, зі слів кінематографічної й біографічної матері, був жалісливий, лише його ніхто не жалів [2, с. 147]. Водночас Божественне начало в Стуса дорівнює тобі (абсолютне «ти», що граматично саме відбивається у Стуса, дорівнює Богові) - людині, що в межах експресіоністичної етико-естетичної системи втілює християнські доброчесності [10, с. 485]. Отож, ідеться про гоєння собою чи то - доростання до себе (оте сакраментальне Стусове самособоюнаповнення). Підсилює думку про тотожність тебе та Бога й наступний режисерський крок - звучання у фільмі поезії «Мов жертва щирості - життя...» зі збірки «Веселий цвинтар», покладеної на музику вокальним дуетом «Тельнюк: Сестри»: «Ти ще на кінчику пера / возносишся увись. / А вже пора? Давно - пора. Спадаючи, молись [...]» [5, с. 161].

Веретельників Василь Стус у подальшому перебігу стрічки лише детальніше відкривається у своєму доростанні. Його постать подана акторкою як фізично приречена (в епізоді фігурує голомозий в'язень, що грає на гребінці «Співають, плачуть солов'і...», тут же чути звуки, ніби закриваються двері карцеру), проте духовно незалежна. Про цю духовну свободу креатора Стуса сигналізують міркування 3 листів до дружини, де світ ототожнюється 3 театром, в якому «на гігантській авансиені багатоповерховій іде дійство» [8, с. 240], а в ньому задіяні герої, які дивляться на себе збоку. Стус-персонаж знаходиться у позиції над й чітко усвідомлює цей стан над-існування: «Тяжко мені писати, люба. Ще тяжче - згадувати. Ще тяжче - думати наперед, чуючи свій безпровинний і неспокутний перед Тобою гріх. [...] Валю! Бачу, деякі знайомі думають, щзо я в розпачі. Ні. Просто я відчув, щуо є щңось, більще за мене, більше за моє уявлення можливого. А за межами можливого немає ні радості 
ні розпачу, бо там діє інша система, якої не хочеться називати» [8, с. 45-46]. Зрештою, над-існування вимагає найскладнішого для фізичної особистості прощання зі спогадом (минулим), недаремно Галина Стефанова гру на гребінці завершує співом «Співають, плачуть солов'ї...», фрагментом, в якому актуалізовано образ із Олесевих «Чарів ночі» - Фауст, якому скуni, глухі $\check{u}$ нечулі боги не дають змоги повернути минуле.

Роман Веретельник Стусове трагічне прощання з минулим переводить в антитетичну площину: драматичне читання акторкою поезії 3 «Часу творчості» «Синочку мій, ти ж мами не гніви...», де смисловий наголос падає на просторовий образ потойбіччя («Мене ж - не жди. Бо вже нема надї / схилитись голова до голови / на щиру радість. Більще не чекай. / Я вже по той бік радісного світу» [6, с. 120]) і муки, що дивиться з пітьми, супроводжується виконанням жартівливої пісні на слова Валентина Лагоди «I в Вас, і в нас хай буде гаразд!», в якій уособлене ідеалістичне життя радянської людини («А ще вам бажаєм - / Вічно молодіть, / До сторіччя жовтня / 3 внуками дожить»), i кадрами ідеологічної Батьківщини-Матері.

Наступний епізод зі Стусом-персонажем своєрідно підсумовує поетове доростання, про яке свідчить зачитувана акторкою поезія «Гойдається вечора зламана віть...», що відкриває збірку «Палімпсести». Ключовим бачиться образ «мій дух басаманить» [7, с. 7], який співвідносний зі Стусовою життєвою орієнтацією на прямостояння. На думку Елеонори Соловей, у цьому вірші «[...] дано весь овид змученої, але несхибної душі, весь обшир духовного єства людини, що виконує своє призначення, свідома його. [...] Тут усе пережсито ще раз наново, від "покути самотності" і зачаєного скрику (в дужках!) "Господи, дай мені жить!" до самоопанування, стоїчної атараксії ("нестраждальності") i готовності: "Сподоб мене, Боже, високого краху!.."» [4, с. 268-269]. Визначений дослідницею смисловий маркер несхибної душі в контексті художнього фільму є вагомою деталлю, яка ознаменовує вищу цінність, що знаково саме в межах експресіоністичної естетики [10, с. 425]. Те, що персонаж 
Стус повноцінно пізнав та усвідомив себе, підкреслює й музичний супровід до кіноепізоду - умиротворена композиція «Канон ре мажор» Йогана Пахельбеля.

За духовним усвідомленням себе приходить фізичний кінець - чим, по суті, завершує «Палімпсест» Роман Веретельник, обігруючи фрагмент інтерв’ю 3 Їлиною Стус, яка переповідає сон: «Одного разу сниться, щэо він каже: "Мам!" Я кажу: "Що?" - "Ти знаєш, я без сорочки". Я кажу: "Чого ти, синок, без сорочки?" - "Нема. Диви". Показує мені руки свої. А в нього тільки клапті висять. "А чого ж ти без сорочки?" - "Нема"» [2, с. 155]. Тут режисер в образі матері повертається до початку стрічки - наявне смислове обрамлення: семантика всепрощення прочитується в іiї монолозі про Василя та його ворогів, де мати просить Господа про прощення їм, синовим ворогам, і собі.

Фізична смерть лише фокусує погляд на винятковості Василя Стуса, що підкреслена в стрічці материнською фразою - «він такий якийсь в мене був» [3], яку Галина Стефанова обіграє мімікою: на обличчі зажуреної жінки з'являється легка благословенна усмішка. I, зрештою, ця смерть не впливає на людську пам'ять про людину і творця, про що й ідеться Романові Веретельнику в останньому епізоді «Палімпсесту»: під музичний супровід - хіт 60-х років «Намалюй мені ніч» Мирослава Скорика, що актуалізує тему повернення («Я до тебе прийду, через гори і доли...»), - Стус-персонаж блукає вечірнім Києвом між людей.

Отож, у короткометражній художній стрічці Романа Веретельника «Палімпсест» за об'єкт дослідження обрана творча особистість Василя Стуса. Режисер, працюючи в межах експресіоністичної поетики, інтерпретує постать Стуса як креатора, за допомогою знакового для нього образу душі (набуває семантики всепрощення, доростання, прямостояння).

\section{ЛІТЕРАТУРА}

1. Василь Стус: Поет і Громадянин. Книга спогадів та роздумів / упоряд. В. Овсієнко. Київ : ТОВ «Видавництво “Кліо”», 2013. 684 с.

2. Нецензурний Стус. Книга у 2-х частинах. Частина $1 /$ упоряд. Б. Підгірного. Тернопіль : Підручники і посібники, 2002. 336 с. 
3. Палімпсест: фільм; режисер Р. Веретельник. 2014 рік // Музей Василя Стуса. URL : https://stus.com.ua/video/ $368 \mathrm{c}$.

4. Соловей E. Українська філософська лірика: навч. посібник. Київ : Юніверс, 1999.

5. Стус В. Вибрані твори / упоряд. Д. Стус. 2-ге вид. Київ : Смолоскип, 2014. 872 с.

6. Стус B. Зібрання творів : у 12 т. / [редкол. : Д. Стус та ін.]. Київ : Факт, 2007 2009. T. 3 : Час творчості / Dichtenszeit. 2008. 752 c.

7. Стус В. Зібрання творів : у 12 т. / [редкол.: Д. Стус та ін.]. Київ : Факт, 2007 2009. Т. 5 : Палімпсести (Найповніший незавершений корпус). 2009. 768 с.

8. Стус B. Твори: у 4 т., 6 кн. / [ред. кол. С. Гальченко, М. Гончарук та ін.]. Львів : Просвіта, 1994 - 1999. Т. 6. Кн. 1: Листи до рідних / упор. О. Дворко, М. Коцюбинська. 1997. $496 \mathrm{c}$.

9. Стус Д. Василь Стус: життя як творчість. Київ : Факт, 2005. 368 с.

10. Энциклопедический словарь экспрессионизма / гл. ред. П. М. Топер. Москва : ИМЛИ РАН, 2008. 736 с.

\section{REFERENCES}

1. Ovsiyenko, V. (Ed.). (2013). Vasyl' Stus: Poet i Hromadyanyn. Knyha spohadiv ta rozdumiv [Vasyl Stus: Poet and Citizen. The book of memories and reflections]. Kyiv: Klio. [In Ukrainian].

2. Pidhirny, B. (Ed.). (2002). Netsenzurnyy Stus. Knyha u 2-kh chastynakh. Chastyna 1 [Obscene Stus. The book is in 2 parts. Part 1], Ternopil': Pidruchnyky i posibnyky. [In Ukrainian].

3. Veretel'nyk, R. (Director). (2014). Palimpsest [Palimpsest]. Retrieved from: https://stus.com.ua/video/ [In Ukrainian].

4. Solovey, E. (1999). Ukrainska filosofska liryka [Ukrainian Philosophic Lyrics]. Kyiv: Yunivers. [In Ukrainian].

5. Stus, V. (2014). Vybrani tvory [Selected Works]. (2 ${ }^{\text {nd }}$ ed.). Kyiv: Smoloskyp. [In Ukrainian].

6. Stus, V. (2008). Zibrannya tvoriv [Collected works]. (Vol. 3: Chas tvorchosti / Dichtenszeit). Kyiv: Fakt. [In Ukrainian].

7. Stus, V. (2009). Zibrannya tvoriv [Collected works]. (Vol. 5: Palimpsesty (Naypovnishyy nezavershenyy korpus)). Kyiv: Fakt. [In Ukrainian].

8. Stus, V. (1997). Tvory. [Works]. (Vol. 6, part 1). Lviv: Prosvita. [In Ukrainian].

9. Stus, D. (2005). Vasyl' Stus: zhyttya yak tvorchist' [Vasyl Stus: life as creativity]. Kyiv: Fakt. [In Ukrainian].

10. Toper, P. M. (Ed.). (2008). Entsiklopedicheskiy slovar' ekspressionizma [Encyclopedic Dictionary of Expressionism]. Moskow: IMLI RAN. [In Russian].

\section{АННОТАЦИЯ \\ Ольга Пунина. Интерпретация личности Васыля Стуса в художественном фильме Романа Веретельника «Палимпсест».}

В статье ключевым объектом исследования выступает творческая личность Васыля Стуса, какой она представлена в короткометражном художественном фильме 2014 Романа Веретельника «Палимпсест». Доказано, что режиссер работает в пределах поэтики экспрессионизма и интерпретирует индивидуальность Стуса как креатора, с помощью знакового для него образа души.

Ключевые слова: образ, экспрессионизм, художественный фильм, личность, интерпретация, смысл, литературно-бытовые материалы. 


\section{ABSTRACT \\ Olga Punina. Interpretation of Vasyl Stus personality in Roman Veretelnik's «Palimpsest» feature film.}

The article focuses on the creative personality of Vasyl Stus in a short feature film by Roman Veretelnik. His film «Palimpsest» (2014) - the first in Ukraine feature film about the writer Stus. So far, film criticism and comparative studies have not explored this film.

In «Palimpsest» the main role (writer Vasyl Stus) is performed by actress Galina Stefanova. She also plays other characters - the judge and the writer's mother. From the form side, Roman Veretelnik uses the principle of palimpsest - the imposition of episodes. With the help of this principle new meanings arise.

The image of the writer the director creates with the help of a collage of his letters, memories of him, documentary shots. This collage helps to see one of the main images - the soul. This image correlates with the biographical personality of Vasyl Stus.

In the feature film Palimpsest, the image of the writer is formed by three points of view. The first point of view is the mother, for whom the son is destroyed by enemies. But all enemies must be forgiven of their sins. The image of the mother is strengthened by divine semantics. The second point of view comes from the judge. He condemns and humiliates Stus. The image of the judge is filed as grotesque. The third point of view is the main one, the writer himself. He is served in prison. It's in prison that Stus really creates. Although he is alone. He must give up physical life. But his spirituality becomes even stronger. Hence the image of his strong spirit.

It is proved that the director works within the poetics of expressionism and interprets Stus's personality as a creator.

Key words: image, expressionism, feature film, personality, interpretation, meaning, literary and everyday materials.

Стаття надійшла до редакційної колегії 14.11.2017 року 